In this series of marine beds we have at the bottom lagoon beds, as I call them, which may represent a similar state of things to what we see at Christchurch, or Poole, or Weymouth, or any place where we have mud banks left is a ven shallow, between each returning tide. We still firr here leaves of rrees, many of them doubtless acrinaiging the lagoons, which have so slowly decayed, that they are overgrown with zoophytes; crowds of oysters are met with; we find the remains of shorecrabs, which from our knowledge of existmg species, we infer, overran the muddy shore; the callianassa, a prawn-like creature, which bored through the mud; limpets, arcas, corbulas, and many other shell-bearing molluscs, passing their lives, dying, and becoming buried in the sediments of the sheltered lagoons. This lagoon condition went on until the gradual sinking has permitted the ever-encroaching surf to break over the lagoon barrier, to rush in, and in time overwhelm them with rolled shingle and sea-sand. We still trace the lagoon condition for a iriile or so east, where it is represented by cigar-ash coloured sands, impregnated with salt, and coloured with this dark tint of carbonaceous matter. These sands contain very perfect remains of branches of a coniferous

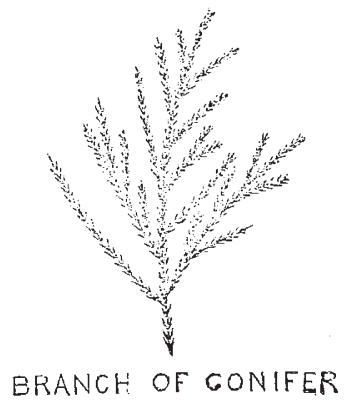

FIG. 3. - Taxodizm.

tree resembling the genus Dacridiam and large pieces of racius. It should be mencioned that this is the rarlisst cactus known, and that the spines are found to tro siill flexible. The sands are in other places crowded with fruits something like those met with at Sheppey. Unfortunately the salt contained in them efforesces and splits all these specimens into fragments.

I may just tell you that at Hengistbury Head we have decper sea deposits, with sharks' teeth and bones. At Highcliff, Barton, we have relics of a sea swarming with life, myriads of fossil shells may be collected on the cliffs, whilst still further on at Hordwell, we have beds showing that the land arose again, affording suitable conditions for the growth of luxuriant paIms, and was the haunt of the alligator, turtle, and other reptiles which are now confined to tropical countries.

Fig. 2 is a view of the Valley of the Bourne at the time referred to above; a description will be given in the next article.

(To be continued.)

\section{GEOGRAPHICAL CURTOSITIES}

TURING the meeting of the International Geographical Congress at Paris in. 1875, the National Library opened an exhibition supplementary to that which was held in the Tuileries. Although very rich in documents and modern geographical works, the great national institation did not wish to show simply a duplicate of the collections exhibited at the Tuileries, and it therefore brought cut only ancient and rare objects which the rules of the cstablishment wisely forbid to leave the building. Thus it showed to the public neither its great topographical maps, such as those of Cassini, van der Maelen, \&c., nor iis recent atlases, its numerous geological maps, its hydrographic charts of the French, English, and other Admiralty Departments, But, thanks to M. Leopold Delisle,
Administrator-General of the National Library, and to M. E. Cortambert, Librarian of the Section of Maps and Plans, there was exhibited in the magnificent Mazarin Gallery a collection unique of its kind, and to which tive Departmenis of Printed Books, Manuseripts, and Engravinirs contributed. The objerts extibised bilo:ged generilly to Group IV., devoted to Historical Geogiaphy and the History of Geography, and comprised, besides ancient and modern works and MSS. treating of geography and its history, ancient maps and globes, instruments used by ancient geographers, astrolabes, sundials, \&c.

The success of the exhibition in the Mazarin Gallery inspired the Administration of the Library with the happy idea of transforming this temporary exhibition in to a permanent institution. This has been established in the ground-floor of what is known as the "Salle des Globes", and in the two rooms which look out upon the great court of the Rue Richelieu, has been recently opened to the public who are admitted on Tuesdays from ro to 4 .

Although the limited space at disposal in these apartments has not permitted the transference of all the objects exhibited in the Mazarin Gallery, and although the Departments of Manuscripts and Printed Books have kept possession of some of the valuable documents lent on the occasion of the Geographical Congress, the exhibition is nevertheless of the greatest interest on account of the rarity of the objects which it contains. Space forbids us to give a complete list of the many objects exhibited, though we are able, through the courtesy of the editor of La Nature, to give illustrations and descriptions of a few of the curiosities. There are nearly 500 objects altogether, and those who desire a complete descriptive catalogue of them should procure No. 178 of the French journal just referred to.

On entering the first room of the exhibition the visitor is at once struck with the large dimensions of the two great globes of Coronelli, made, in 1683 , by order of the Cardinal D'Estrees, who presented them to King Louis XIV. Ore of the most curious objects shown in this room is a map of the world, probably of the minth or tenth century. It is a copy of one which appeared in a Commentary on the Apocalypse written by Beatus, a benedictine of the monastery of Valcovado in Leon, who lived in the eighth century. The original of which the one exhibited (Fig. I) is a copy, belongs to the library of Turin. It shows strikingly the wonderful notions which these old monks had of the universe, and especially of the earth in which they dreamed their uneventful lives away. Four winds, represented by the grotesque figures seated upon the skin or leathern bottles, and holding shells in their mouths, indicate not the four cardinal points, but the collateral points, where the sun rises and sets at the summer and winter solstices. The orientation of the map, as was for long the custom in the middle ages, places the east at the top, the west below, the nortb on the left, and the south on the right. A circular ocean, the old river Oceanos of Homer, surrounds the world. If we examine the interior of this strange mappennonde, Europe will be seen on the left, Africa on the right, and Asia at the top. The Mediterranean is represented by a very regular parallelogram, extending from east to west. A not less regular branch of this sea occupies the place of the Archipelago, the Black Sea and the Sea of Azov, and bounds Europe on the east, the north-east point of the continent being indicated by the words Hic Caput Europe (Europæe). Islands uniformly square are spread over the Mediterranean; we may recognise under strange names, Corcyra, Cyprus, Samos, Sicily, Corsica; the name Tassis, which may also be noticed, designates, no doubt, the City of Tarsus, which the author evidently regards as an island.

In the surrounding ocean appear other islands not less fantastical. On the east the island of Crisa and Algure 
(for Argire), in allusion to the region of gold and silver of the ancients, in trans-Gangetic India; on the north-east the Island of Tule, which recalls the famous Thule; Britannia ; then the Island of Scotia, which, however, is not Scotland, as many might be apt to think, but the original home of the Scots, Ireland; for it was not till about the twelfth century that the name was fairly transferred to North Britain.

The orography of Europe is shown, partly in enormous cones, partly in elongated masses, five principal chains, of which only one is named, the Mountains of Gaul (Montes Galliarum), without doubt, the Pyrenees. The hydrography is wretchedly meagre. The largest river is correctly set down as the Danube (Danubu), but what a curious course is given to it! The second in extent is the Tagus, under the name of Tazus, which in utter contempt of geography, discharges itself into the Mediterranean. What considerable river is that which flows towards the east under the name of Eusis, a name still applied in Asia to a large river situated almost opposite to this one? Perhaps it may be meant for the Pontus Euxinus itself, the Black Sea ; for to mistake a sea for a river was not an uncommon thing with these old geographers.

The political geography is of a higher kind than the physical geography. To speak only of Gaul we find mention made of Aquitaine, Toulouse, Gallia Lugdunensis,

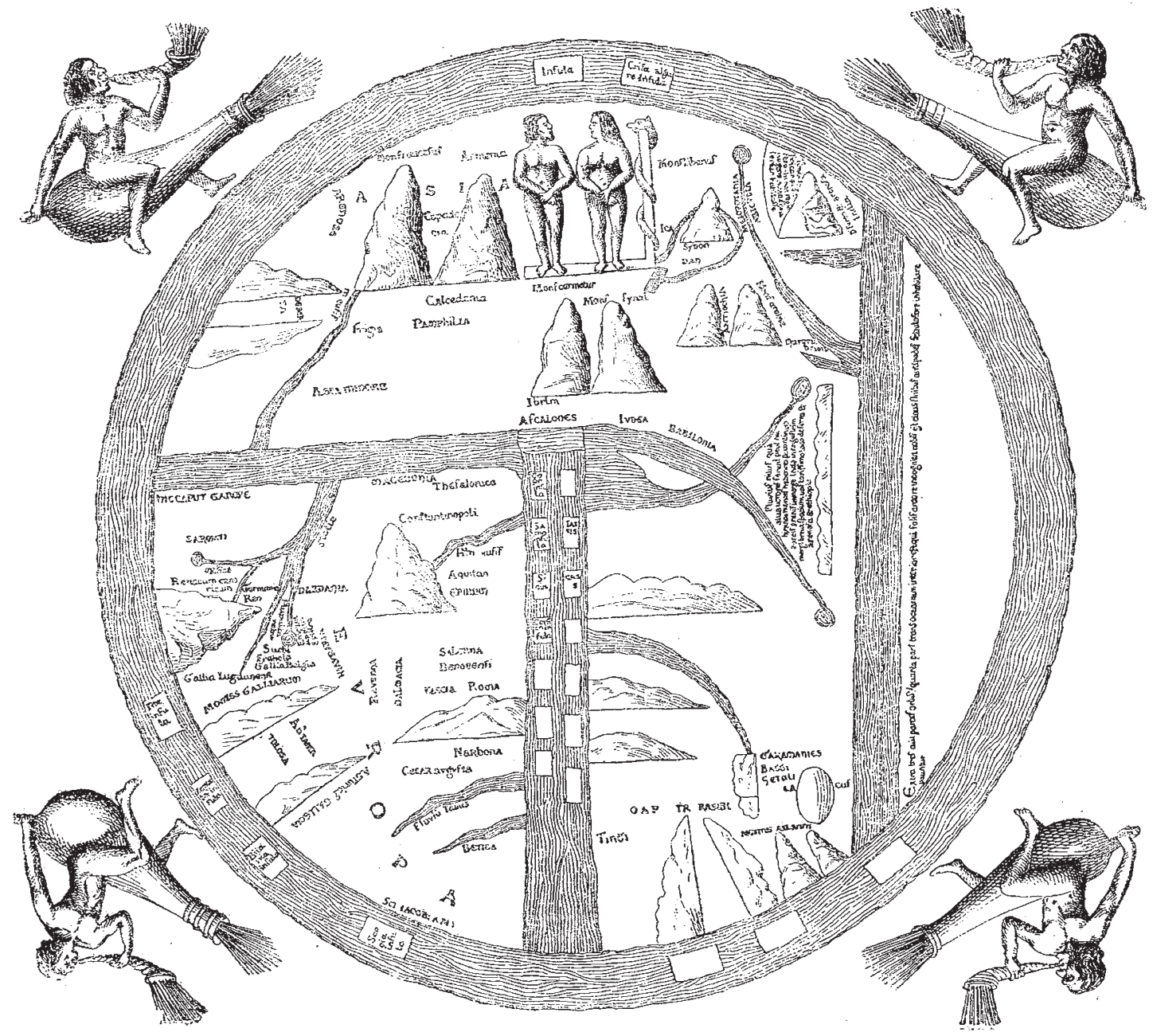

Fig. I.-Map of the world contained in Beatus's Commentary on the Apocalypse (roth c.).

and Gallia Belgia ; we also find Francia, which, however, does not stand for France but for Franconia.

In Asia, on the spot, no doubt, where Paradise was supposed to have been placed, appear Adam and Eve, in a grotesque position, and near them the serpent, who, however, has nothing tempting about him. Ten conical mountains surround this curious scene, without names except Libanus, the Caucasus, Carmel, and Sinai. Only. three rivers flow in this vast space : first the Jordan, which encompasses Mount Lebanon in a very strange way; the Euphrates, which, though it bears no name, may be divined by the name Mesopotamia written on its banks; and then the Eusis, that mysterious Eusis to which we referred above.

The countries and the towns are more abundantly treated, though scattered pretty much at hazard. Jerusalem holds the first place, under the abbreviation, Ihrlm; Judea, Ascalon, Sidon, Antioch, Asia Minor, Phrygia, Mesopotamia, \&c., are represented in situations more or less inexact.

In Africa, what strikes one at first is the Nile, the enormous Nile, divided near its sources into two branches, each issuing from a lake; it falls into the sea by a mout' larger than that of the Mediterranean itself. A note in- 
serted between its sources tells of the gold which is mixed with the sand of the river, a vast lake which it traverses, and the sandy deserts of Ethiopia, through which it flows. The only other river seen in Africa is one without a riame, which descends from the country of the Garamantes and falls into the Mediterranean ; it is probably the Bagradas --the Medjerda of the present day. The mountains of Africa are but poorly shown. After Mount Atlas (Montes Atlanni), which is neither in its place nor very markedly brought out, there may be noticed three mountains which abut in the Mediterranean, and two steep and sharppointed mountains designated by the scarcely legible

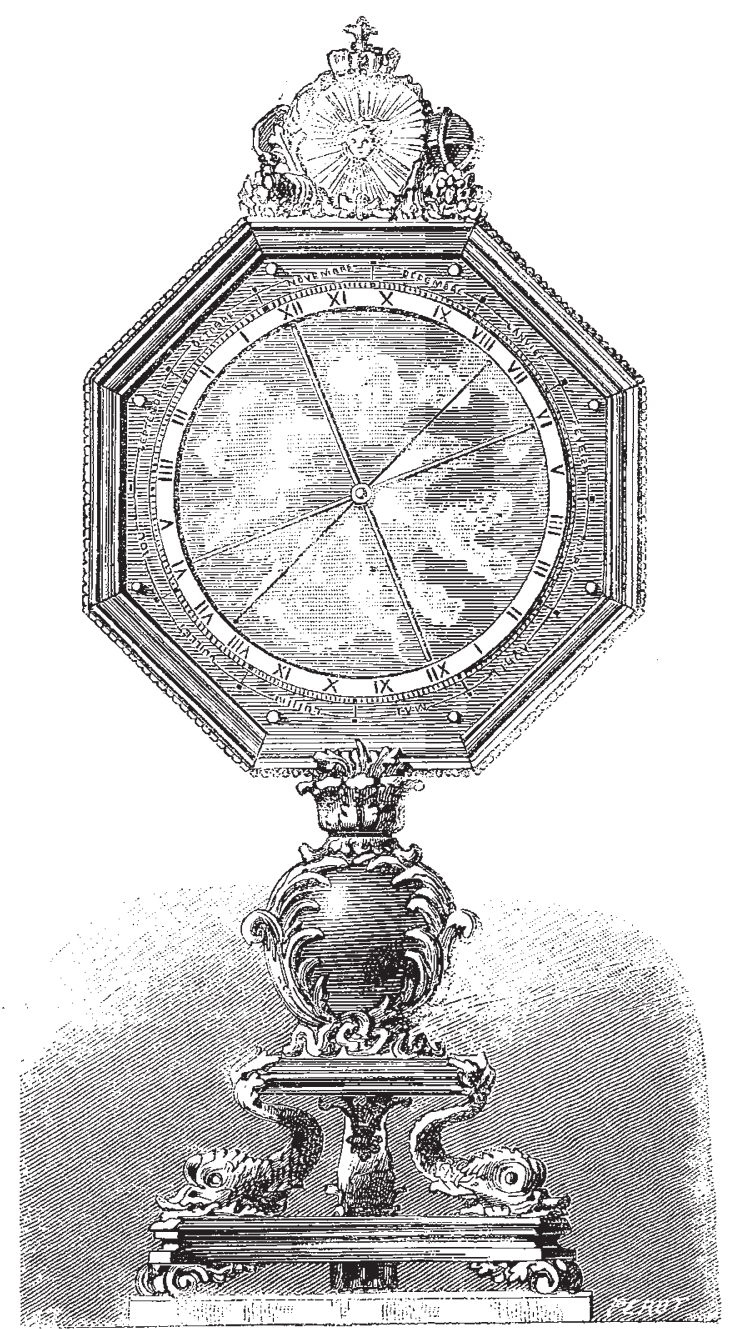

FIG. 2.-Copper cosmographic apparatus.

words, duo Alpes Contra Arasibi; this should perhaps be read Contraria sibi, i.e., two mountains opposite each other, forming, as it were, two walls between which is a narrow passage. But where exactly are they?

A note inserted in the south of the map tells us that, independently of the three points of the known world, there is beyond the ocean a fourth part which is unknown to us on account of the heat of the sun, and on the confines of which, it is fabled, adds the author, that there are Antipodes. ${ }^{\mathrm{I}}$

A reproduction of this map belonging to the Irth

- For the above details we are mainly indebted to an article recently pulshed by M. E. Cortambert. century shows a marked progress on that which we have just described.

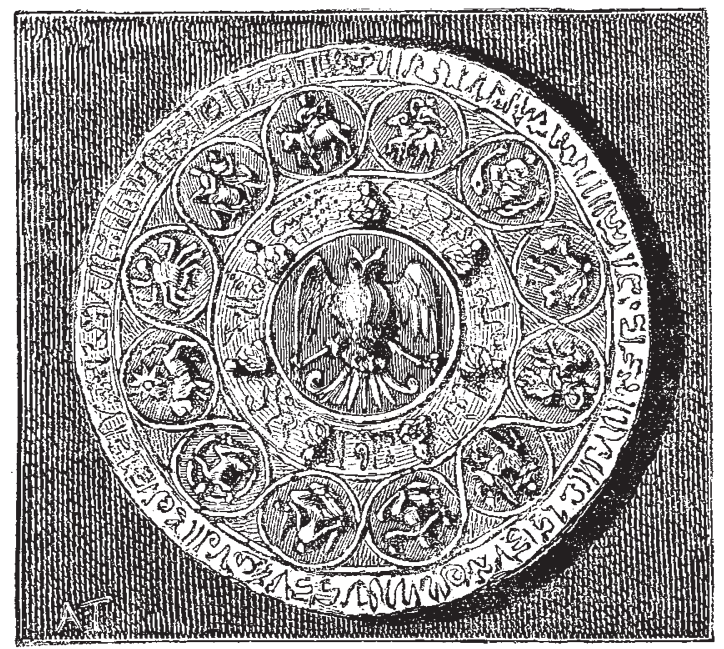

FIG. 3.-Arab zodiac (one-fifth size of original).

The room in which this map is exhibited contains many equally curious objects, some of them of great rarity and

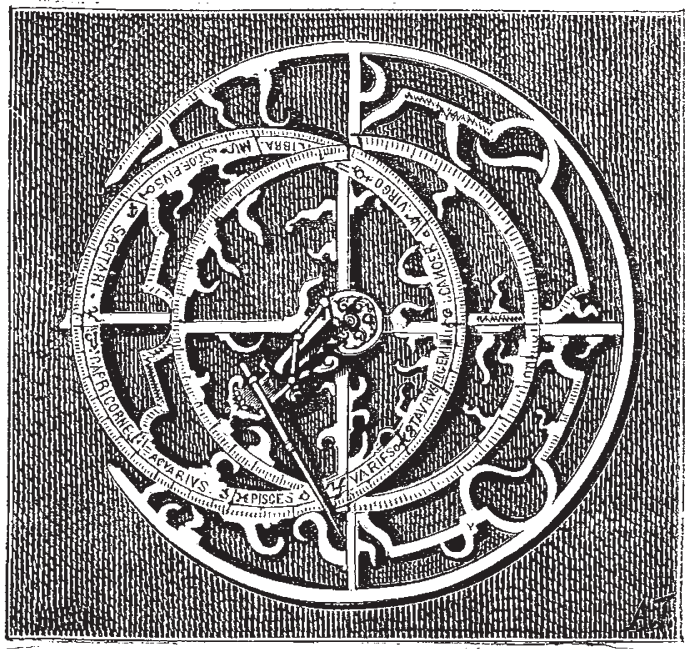

Fig. 4-French astrolabe (one-fifth size of original).

value. Among these we may mention a copper cosmographic apparatus (Fig. 2) by Thuret, of date I725. On

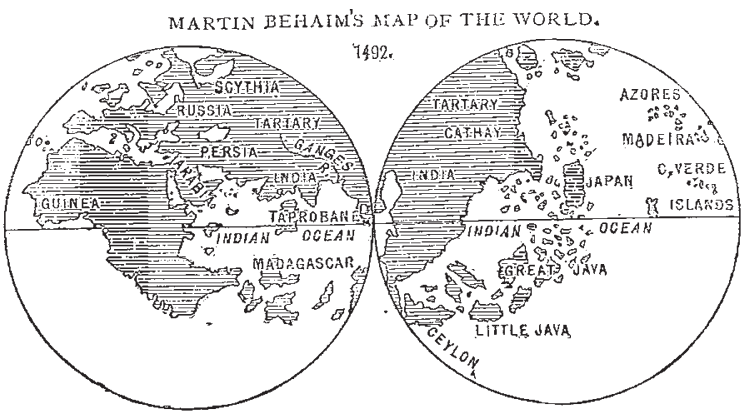

FIG. 5.-Martin Behaim's map of the world.

one face are represented the northern constellations and the signs of the zodiac, as well as the correspondence of 
these signs with hours and days; on the other side is shown the movement of the planets around the sun. It is worked by means of a clockwork mechanism in the interior, and is made to indicate the days, months, and years. In other rooms are shown the curious Arab zodiac represented in Fig. 3, and a French astrolabe (Fig. 4) made by François Chassignet, and of date
Rome, 1622 . Another interesting object is a facsimile map of the world, painted on parchment by order of Henri II. (I 547-1559). Some critics, among others M. D'Anezac, date it as far back as the time of François I. $(1515-47)$. In Fig. 6 we have reproduced a portion of South America after this curious document.

Among other objects is a facsimile of the well-known

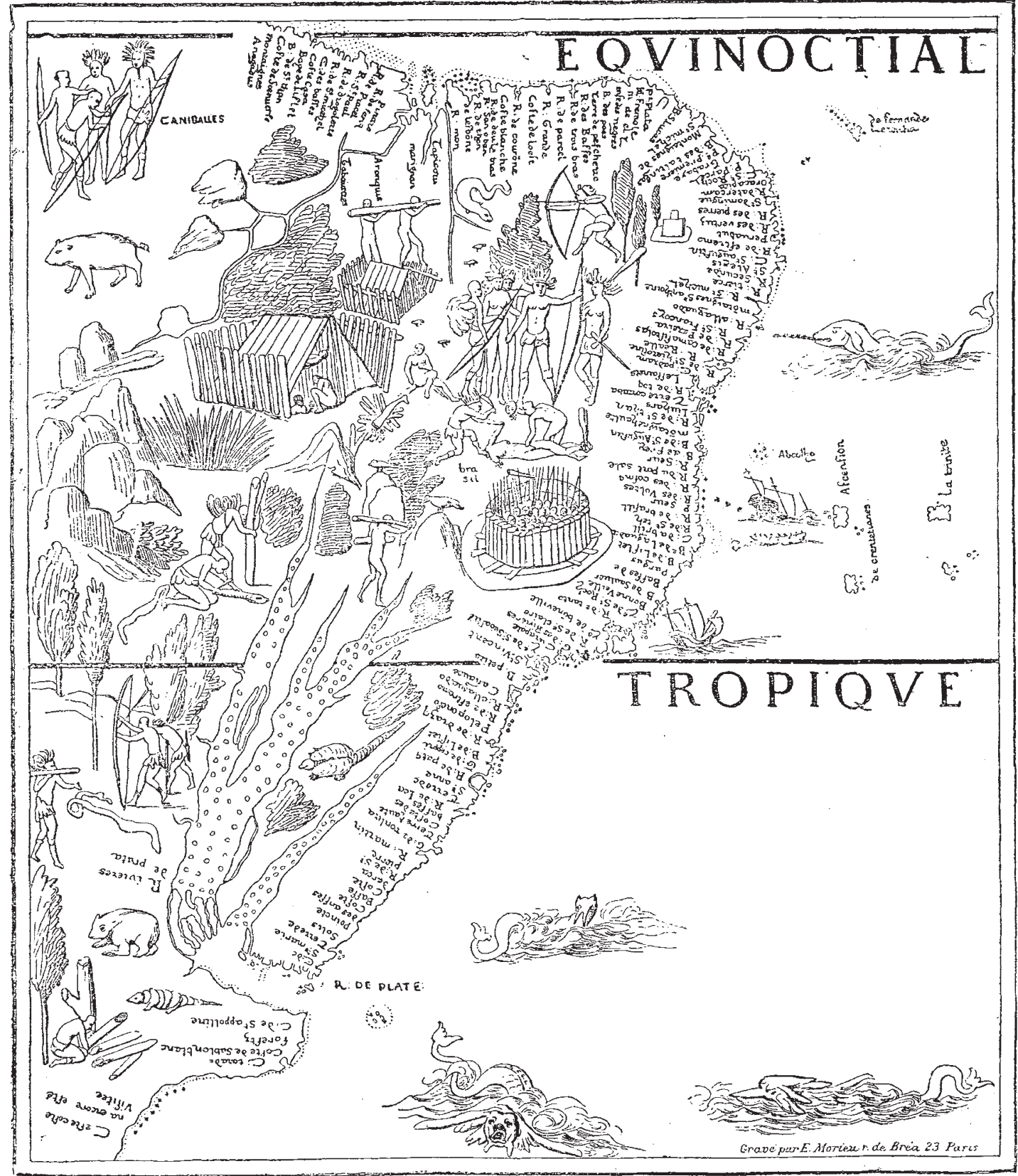

Fig, 6. -North-east region of South America (t6th c ).

globe of Martin Behaim, of date 1492, the original of brated map of the world of Sebastian Cabot, of date 1544. which is at Nuremberg. This globe is extremely curious, specially on account of the lacuna in the region where America should be, that continent not having been discovered when the globe was made. An idea of the contents of this globe may be obtained from the illustration, A valuable legend in Latin and Spanish informs us, among other things, that John and Sebastian Cabot landed on the new continent in 1494

Such are a few of the objects exhibited in this extremely , interesting and instructive collection. No doubt many Fig. 5. There is also the only known copy of the cele- of our readers will be glad to know of its existence, and 
those who take an interest in the progress of geography will doubtless think with us that such an exhibition adds one more to the many attractions of Paris; now that the Loan Collection is closed, nothing at all approaching it cxists in London.

\section{TEMPERATURES AND OCEAN CURRENTS IN THE SOUTH PACIFIC}

I $N$ the Annalen der Hydrogratitie und maritimen $M e$ teorologie (Jahrg. iv., I876, Heft 6, p. 219), Herr von Schleinitz, a member of the recent expedition in the German corvette Gazelle, states his views on ocean temperatures and currents; these are somewhat different from those expressed by Sir C. Wyville Thomson (Proc. Roy. Soc., vol. xxiv.), which are based on the data obtained during the Challenger expedition. The Gazelle, after leaving Auckland (New Zealand), pursued a course almost due north as far as the Fiji Islands; thence she proceeded to the Samoan Islands, situated at a short distance north-east of Fiji. After a brief excursion to the Tonga group and back, the Gazelle (from long. $172^{\circ} \mathrm{I} 8^{\prime} \cdot 5 \mathrm{~W}$., and lat. $14^{\circ} 28^{\prime} \cdot 1 \mathrm{~S}$.) sailed some 2,500 nautical miles in a south-south-east direction (to long. $141^{\circ} \mathrm{II}^{\prime} .4 \mathrm{~W}$., and lat. $45^{\circ} 33^{\prime} .6 \mathrm{~S}$.), after which she took a due easterly, and later on, a south-easterly course, to Magellan's Straits (long. $80^{\circ} 30^{\prime \prime} 3$ W., lat. $5 \mathrm{I}^{\circ} 4 \mathrm{I}^{\prime} \cdot 6 \mathrm{~S}$.). The observations of temperature on the long cruise between the Samoan Islands and the Magellan's Straits are of special interest, as the course taken by the Gazelle lies to the south of that pursued by the Challenger.

On the first part of the course described, which has a direction nearly coinciding with the meridian, eight series of observations of temperature were made. The bottom profile of this part shows a peculiar absence of elevations, which is all the more remarkable when compared with any similar profile of the same length in the Atlantic.

The conclusion arrived at by Herr von Schleinitz, and based on the results of his observations is, that in the Pacific the arctic deep-sea current crosses the equator in a southerly direction and meets the antarctic current oniy between lat. $30^{\circ}$ and $36^{\circ} \mathrm{S}$. This is just the reverse of what takes place in the Atlantic, as it seems highly probable from the observations of both the Challenger and the Gazelle expeditions, that in the Atlantic the antarctic deep-sea current passes the equator, running northward of the same to a considerable distance.

Herr von Schleinitz concludes from these latter observations, that if the antarctic deep current enters the North Atlantic, even as a current of limited breadth, it must nevertheless carry enormous quantities of water from the South Atlantic to the North Atlantic, as it is certain that the current has a depth of more than I,Ooo fathoms on the average. He then asks the question, What becomes of this mass of water? There is no strong surface current in existence which carries it back to the South Atlantic; even the current caused by the south-east trade winds runs more towards the Gulf Stream than towards the Brazilian coast current. There seems only one hypothesis possible, viz., that a great part of the water flows through the Arctic Sea and Behring's Strait into the North Pacific, and that may be the cause of the preponderance of the arctic current of this ocean over its antarctic one.

The natural conclusion drawn from this is that the South Pacific, in order to complete the whole circle, gives a great part of its waters to the South Atlantic, and as a proof of this it might be pointed out that the ice limit does not approach the equator so much anywhere as it does in the South Atlantic.

The following facts may also be mentioned as in favour of the hypothesis of a certain regular circulation taking place in the manner described. A comparison of the airisotherms as well as the sea-isotherms both of the Atlantic and Pacific Oceans shows that ( 1 ) the South Atlantic is colder than the North Atlantic ; (2) the North Atlantic is warmer than the North Pacific; (3) the South Pacific is warmer than the South Atlantic.

The higher temperature of the North Atlantic Ocean has hitherto been generally explained by the influence of the Gulf Stream. But a similar current exists in the Nurth Pacific, and yet this is colder. There is no doubt that the Gulf Stream has a warming effect on some European coasts, but it is very probable that considering its comparatively small breadth of about 100 nautical miles, and shallow depth of only Ioo fathoms, the stream is far too insignificant to be able to exercise a perceptible influence upon the climate of the whole North Atlantic and of the coasts surrounding this ocean.

On the other hand it does not seem to have been sufficiently appreciated hitherto, that a very large part of the North Atlantic is filled by water, which has crossed the equator, even if at a considerable depth. However trifling the rise in the temperature of this water, as caused by the passage over the equator, may be, when compared to the general temperature of the South Atlantic, it is nevertheless a fact that there is an important amount of heat, which the South Atlantic loses and the North Atlantic gains, on account of the very large extension of the current. Nor can it be objected with regard to this, that the mean temperature of that mass of water is probably below the mean temperature of air in the North Atlantic, because there is no question of absolute heat, but only of difference of temperatures between the North and South Atlantic.

The excess of water in the North Atlantic, which is not carried back into the South Atlantic by the surface-currents, and which passes through the Arctic Ocean (where it loses the heat it possessed) into the North Pacific, causes a decrease of temperature in the latter, and, proceeding southward, i.e., again crossing the equator and thus absorbing heat, produces an increase of temperature in the South Pacific. Finally, the South Pacific gives back to the South Atlantic a part of that water at a very low temperature, which originally flowed from the latter into the North Atlantic perceptibly heated, on account of its passage through the tropics.

This circulation, however, is not to be understood as if the lowest strata of all the oceans took part in it; on the contrary, there are doubtless only single currents in the lower strata which follow it, while others may flow in an opposite direction. Further observations will throw light on these hypotheses ; those made up to the present are yet insufficient and at times even contradictory. At the same time it must not be overlooked that a constant exchange of water between the lower and upper strata, i.e., currents flowing in a vertical direction, are proved to exist beyond doubt, particularly in certain zones.

In conclusion Herr von Schleinitz considers the oceanic system of currents to be evidently a very complicated and at present obscure one, upon which the observations made on board the Challenger and the Gazelle throw but a very faint light.

The second part of the course pursued by the Gazelle, as described above, did not differ sufficiently in latitude, and therefore could not furnish any data which would be useful or decisive on the subject in question. However, the observations which were made give results in complete accordance with the hypothesis referred to above.

\section{ON THE MEANS OF PROTECTION IN}

\section{FLOWERS AGAINST UNWELCOME VISITORS}

THE phenomena relating to this subject, which have important bearings on the doctrine of selection, have recently been discussed by M. Kerner in an interesting monograph communicated to the Festschrift published on occasion of the twenty-fifth anniversary of the Zoo- 